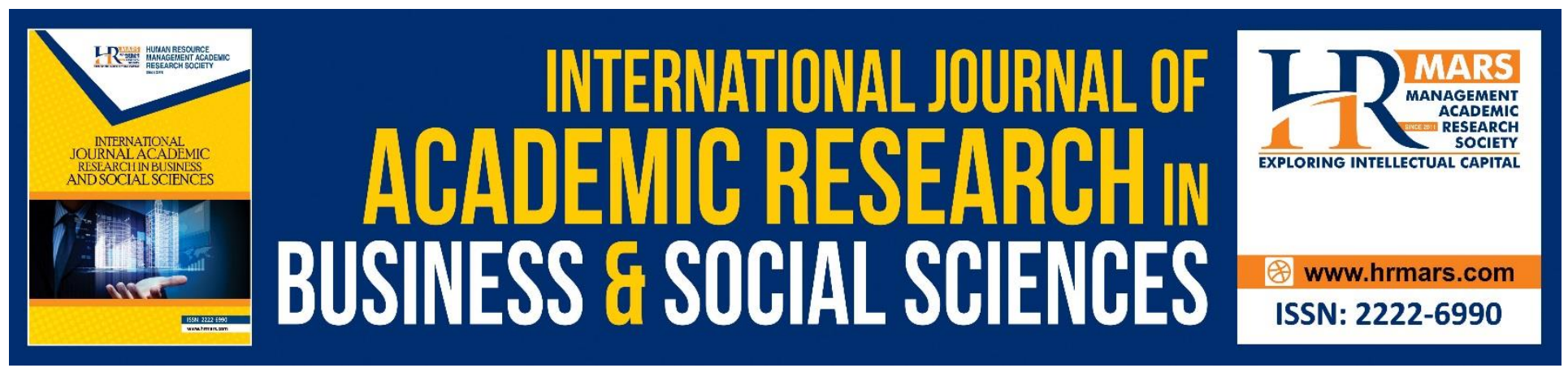

\title{
Emotional Competency Issues Faced by Youths in Malaysia
}

Asma Perveen, Hazalizah Binti Hamzah, Pau Kee, Nurul Ain Binti Mohd Daud, Azizah Othman, Nurul Ain Hidayah Abas, Ebru Morgul

To Link this Article: http://dx.doi.org/10.6007/IJARBSS/v8-i11/4983

DOI: $10.6007 /$ IJARBSS/v8-i11/4983

Received: 04 Nov 2018, Revised: 29 Nov 2018, Accepted: 06 Dec 2018

Published Online: 11 Dec 2018

In-Text Citation: (Perveen et al., 2018)

To Cite this Article: Perveen, A., Hamzah, H. B., Kee, P., Daud, N. A. B. M., Othman, A., Abas, N. A. H., \& Morgul, E. (2018). Emotional Competency Issues Faced by Youths in Malaysia. International Journal of Academic Research in Business and Social Sciences, 8(11), 1039-1055.

\section{Copyright: (c) 2018 The Author(s)}

Published by Human Resource Management Academic Research Society (www.hrmars.com)

This article is published under the Creative Commons Attribution (CC BY 4.0) license. Anyone may reproduce, distribute, translate and create derivative works of this article (for both commercial and non-commercial purposes), subject to full attribution to the original publication and authors. The full terms of this license may be seen

at: http://creativecommons.org/licences/by/4.0/legalcode

Vol. 8, No. 11, 2018, Pg. 1039 - 1055

http://hrmars.com/index.php/pages/detail/IJARBSS

JOURNAL HOMEPAGE

Full Terms \& Conditions of access and use can be found at http://hrmars.com/index.php/pages/detail/publication-ethics 


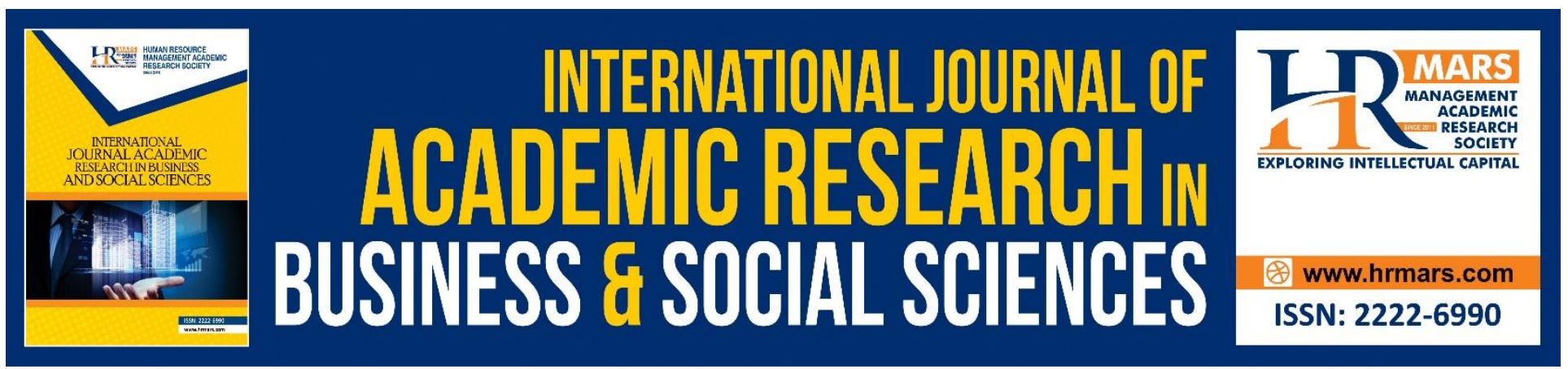

\title{
Emotional Competency Issues Faced by Youths in Malaysia
}

\author{
Asma Perveen ${ }^{1}$, Hazalizah Binti Hamzah², Pau Kee ${ }^{3}$, \\ Nurul Ain Binti Mohd Daud ${ }^{4}$, Azizah Othman ${ }^{5}$, \\ Nurul Ain Hidayah Abas $^{6}$, Ebru Morgul ${ }^{7}$ \\ 1,2,3,6 Department of Psychology and Counselling, Faculty of Human Development, Universiti \\ Pendidikan Sultan Idris (UPSI) Malaysia \\ ${ }^{5}$ Department of Pediatrics, School of Medical Sciences, Universiti Sains Malaysia (USM) Malaysia \\ ${ }^{7}$ Department of Psychology, Ibn Haldun University, Turkey
}

Abstract: Introduction Researchers portray the possibility that emotional competency issues among adolescents can cause behavioural problems in future. They are at risk of becoming dissatisfied and unhappy teenagers and may choose to become involved in negative activities such as gangsterism, bullying, drug abuse, sexual misconduct, and crime" (Kuldas et al, 2015). The aim of the study is to explore emotional issues that are more evident among youngsters. Method Interviews were conducted with 14 professionals and 13 students from the Tunas Bakti schools, secondary schools and universities. Results Through thematic analysis using the MAXQDA software revealed nine themes which are professional competency, living environment, relationship management, self-management, social awareness, self-awareness, juvenile institution negative and juvenile institution positive and ways of coping. Future recommendations, Future studies can help investigate the new findings discovered in the thematic analysis such as the professional competency. Meanwhile, studies in overcoming issues involved in the living environment theme can be explored further.

Keywords: Emotional competency, youths, coping, Self-awareness

\section{Introduction}

Young generations today have more disruptive behaviours. Adults are fearful to deal with their unruly behaviour. Different countries have different labels to describe this group. Some of them are terms such as 'beyond parental control' while some label them as 'disobedient', 'incorrigible', 'unruly' or 'ungovernable' and in addition, this social illnesses faced by young generations demand the governable attention of various individuals as there is a link between their current behaviour and the potential for delinquency and future involvement in criminal activities (Syed Nong \& Mohd Yusoff, 2015). Hashim (2007) stated that "Malaysian teenagers, in general, face various life challenges and 
INTERNATIONAL JOURNAL OF ACADEMIC RESEARCH IN BUSINESS AND SOCIAL SCIENCES Vol. 8, No. 11, Nov, 2018, E-ISSN: 2222-6990 @ 2018 HRMARS

experience distress. They are at risk of becoming dissatisfied and unhappy teenagers and may choose to become involved in negative activities such as gangsterism, bullying, drug abuse, sexual misconduct, and crime" (Kuldas et al., 2015).

This research was conducted as part of the Fundamental Research Grant Scheme (FRGS) and aims to develop an Emotional Competency Module to overcome emotional competency issues among adolescents. This research involves a qualitative study which aims to explore emotional issues that are more evident among youngsters.

\section{Literature Review}

A qualitative case study research by Fadilah (2012) found that teachers teaching at the Jerantut Tunas Bakti juvenile school experienced stress due to duty burden, juvenile training misconduct, limited resources and time, work environment and interpersonal communication. Whereas, Azizi, Kiaw Geok and Amir Hamzah (2004) showed that vocational, religious knowledge and counselling programmes were less effective than the co-curriculum and academic programmes. On the contrary, Hezzrin, Nor Jana, Norulhuda and Mohammad Rahim (2016) suggested that physical facilities, program facilitation skills, facilitator attitude, teaching methods, administrative support and program evaluation were effective. The different findings will be explored further in the qualitative study in this research.

Other studies showed different factors that affected the emotional intelligence of adolescents. Past researches revealed that family living conditions (Afzal \& Afzal, 2016; Fatimah Hanim, Mahlindayu, Muniruddin, Nik Nabila Ramiz \& Nur Ili Diyana, 2013) and media use (Abdelkader \& Elnakeeb, 2017) affected the emotional intelligence level of adolescents. Communication skills had a positive relationship with emotional intelligence (Najib, Che Su \& Zarina, 2015) and customer relationship management (Alsharari, Fadzil Shah, Che Azlan \& Rushami Zien, 2017). Moreover, Abdollahi, Yaacob, Talib and Ismail's (2015) study revealed that emotional intelligence and social anxiety predicted cigarette smoking behaviour among high school adolescents.

Meanwhile, emotion regulation issues were also shown in the studies conducted by Braet et al. (2014), Maizatul Akmal Mohd, Norhaslinda and Norhafizah (2013) and Balluerka, Aritzeta, Gorostiaga, Gartzia and Soroa (2013) whereby lack of emotion regulation and emotional intelligence (Castilho, Sérgio, Carvalho, Marques \& Pinto-Gouveia, 2017) caused depression and can be overcome through problem-based action. Findings also showed psychological issues such as shyness (Zhao, Kong, \& Wang, 2013; Zhao, Tan, Gao, \& Wang, 2017), social support (Zhao et al., 2013), loneliness (Zhao et al., 2017), psychological adjustment (Cobos-Sanchez, Flujas-Contreras, and Gomez-Becerra, 2017), perceived stress and suicidal ideation (Abdollahi, Carlbring, Khanbani, and Ghahfarokhi, 2016) also affect emotional intelligence. Previous studies provided limited information on the factors that affect emotional intelligence. Hence, this research aims to find out emotional issues experienced by youths as a whole in this country through the qualitative study. 
INTERNATIONAL JOURNAL OF ACADEMIC RESEARCH IN BUSINESS AND SOCIAL SCIENCES

Vol. 8, No. 11, Nov, 2018, E-ISSN: 2222-6990 (C) 2018 HRMARS

\section{Methodology}

For this qualitative study, 14 professionals and 13 students from the Tunas Bakti schools, secondary schools and universities were interviewed. The qualitative study used an interview protocol. The researchers were all involved in the development of the interview protocol where they came up with questions which based on the four domains in the Goleman's Theory of Emotional Intelligence (selfawareness, self-management, social awareness and relationship management). The six phases of thematic analysis method was used to analyse the interview transcripts. MAXQDA software was used to analyse the data.

\section{Results}

\section{Table 1: Thematic Analysis}

\begin{tabular}{|c|c|}
\hline Themes & Sub-themes \\
\hline 1. Professional competence & - \\
\hline 2. Living environment & $\begin{array}{l}\text { Negative lifestyle } \\
\text { Family background } \\
\text { Education system } \\
\text { Social media }\end{array}$ \\
\hline 3. Relationship management & $\begin{array}{l}\text { Express emotions } \\
\text { Communication } \\
\text { Problem solving }\end{array}$ \\
\hline 4. Social awareness & Interpersonal relationship \\
\hline 5. Self-management & $\begin{array}{c}\text { Motivation } \\
\text { Maturity } \\
\text { Controlling emotion } \\
\text { Stress management }\end{array}$ \\
\hline 6. Self-awareness & $\begin{array}{c}\text { Psycho-biology of emotions } \\
\text { Emotion regulation } \\
\text { Lack of self-acceptance } \\
\text { Understanding emotions }\end{array}$ \\
\hline 7. Institution negative & $\begin{array}{c}\text { Future plan } \\
\text { Lack volition } \\
\text { Punishment } \\
\text { Caretaker assertiveness } \\
\text { Away from family } \\
\text { Stuck here. } \\
\text { Tight schedule } \\
\text { Stress } \\
\text { Death of parents } \\
\text { Feeling sad }\end{array}$ \\
\hline
\end{tabular}


INTERNATIONAL JOURNAL OF ACADEMIC RESEARCH IN BUSINESS AND SOCIAL SCIENCES Vol. 8, No. 11, Nov, 2018, E-ISSN: 2222-6990 @ 2018 HRMARS

\section{Institution positive}

Positive change

We just talk straight to the point

Scheduled work

Unity-brotherhood

Learning skills

\section{Ways of coping}

Interpersonal skills

Suggestions for module

Healthy activities

Teaching social intelligence

Parenting skills

Emotional management skills

Self-awareness skills

Social religious values and respect

Counselling

Professional competence. The first theme that was identified from the thematic analysis was professional competence. This theme was identified from the professional responses only. There were 9 coded segments that mentioned about issues related to professional competency in handling emotional problems among adolescents. STB Taiping professional responded that the juvenile rehabilitation centre had trouble caring for all the residents there by saying that, "now it's a bit difficult even if 2 people work to handle with 243 students today, it's a bit hard ... for this which we're managing our work hours, it's so hard. For us to handle, ask to handle everything". Meanwhile, a counsellor at STB Marang mentioned that, "They scared because I was fierce. It's not fierce but strict. Because at the institution, the principal is like this, the deputy is like this. We bring along our attitude. We cannot be like someone else for ... If I be like someone else, I cannot live here" further showing that personality issues may affect their performance as a counsellor.

Living environment. The second theme is living environment. All professionals believed that the living environment of the adolescents affected their emotional competency. However, student interviewees did not share this same view. There were 40 coded segments that mentioned this theme. UKM and UPSI professionals say that environment is the cause for emotional problems among adolescents. Some of the sub-themes identified under living environment were regarding their negative lifestyle, family background, social media and education system. Some professionals also shared that living a negative lifestyle was a contributor to the issue. For example, STB Taiping professional mentioned that, "... but kids nowadays, they can't do that thing, easily got tired, kind of like that, they want "okay go to the TV room", even every day, that's okay. It's like that. It's okay, they want to relax, do not want to sit under a sun, it's okay if they spend 4 hours in the room, watching TV every day, eating, drink, going back to sleep, eating, drink, then go back to sleep. Like that, they do like a home style. Ha like that".

Whereas several others mentioned about family background, social media and education system being an issue among adolescents. For example, family background issue was mentioned by 
STB Sg Besi professional who pointed out that, "Broken family is caused the problem". Meanwhile, a professional from SMK Sultan Mansor said, "excess usage of handphone" as a factor of emotional issues faced by youths whereby an UPSI professional mentioned that social media caused suicide.

Education system. A professional from UPSI shared that education system was also a cause of emotional problems as they focused more on memorising than teaching responsibility. The UPSI lecturer stated, "they only teaching you 24 values that you have to memories and another thing .. because education system make me .. even examination system just to get A. Find ways to get A's . And I think parents spend a lot of money for their children for tuition . Tuition and tutorial".

Relationship management. The third theme is relationship management. There was a total of 84 coded segments in this theme. Some of the sub-themes that led to the emergence of this theme were express emotions, problem solving and communication.

Express emotion is the ability to talk or show their true feelings in a social setting. Examples of professional and student responses regarding emotion expression are when the STB Taiping professional mentioned that, "If there any problems, he just with his friends, doesn't care of anything. If we want to check, he refuses." and S01 said, "I didn't cry a lot because I am a person when it comes to emotion, since my childhood, I don't know why it is quite hard for me to express my emotion. I'm that kind of person. I always say to myself".

Problem-solving. Meanwhile, problem solving in relationship management is the process involved in generating solutions to handle a problematic situation (Erözkan, 2014). STB Telok Air Tawar professional mentioned that, "There are some trainee that just follow him. They cannot decide on themselves anymore. So they follow. These are the most common people that become the bully victims". Whereas S09 said, "Sometimes I have that feeling. Because sometimes, there is some people that bully me. But the bully is not real bully, just teasing. I don't mind about it. But sometimes I accidentally take heart".

Communication as quoted in a study by Hassan, Saeid, Hashim Fauzy and Khalil (2014) that communicative effectiveness is deliberate behaviour aimed at augmenting the result of an interpersonal meeting (Campbell, 1999). Communication according to Goleman (2001) is the competence that deals with compromising emotional information, listening and sharing information and being well receptive to good and bad news in an organizational setting. The STB Sg Lereh professional mentions that, "Communication skills because sometimes they didn't mean to hurt their friend's feeling but maybe in now in the era, it is a trend. That kind of words, it is becoming different and weird". Meanwhile, S08 said that, "I don't know. Maybe from the way I talk, my friend told me that I'm easily offended... maybe it's the pressure that causing me to behave like this, if I feel I can't do it then my academic would be... Allah, I don't know which area needs improvement. I'm confused, so I ... I wanted to apologize but people might be afraid of doing the same thing to me." 
INTERNATIONAL JOURNAL OF ACADEMIC RESEARCH IN BUSINESS AND SOCIAL SCIENCES Vol. 8, No. 11, Nov, 2018, E-ISSN: 2222-6990 @ 2018 HRMARS

Social awareness. This theme has 45 coded segments from professionals only. Students lacked awareness of their internal feelings while communicating with others. The main code that represented social awareness was interpersonal relationship. According to Hsieh, Wang, Fan and Huang (2014), interpersonal relationship is the usage of thoughts, language and emotions when interacting with others. Some of the sub-categories that helped explain interpersonal issues were social learning, empathy, need for attention, peer support, teacher support and other relationships. A UKM professional shared that, "Social actually it comes from the internal first". Besides one of the professionals shared that adolescents lacked empathy.

Self-management. Around 96 coded segments were identified from the interviews with professionals and students. The sub-themes that were grouped into self-management are motivation, maturity, controlling emotions and stress management. Motivation is the internal goal to complete a task (Pelz, 1962). Motivation is a way to help manage emotions (Goleman, 2001). For example, STB Telok Air Tawar professional says that, "We need the firm assertion so that the residents have to achieve something to get something". S01 also says that her motivation level depends her sleep routing in the mornings, "Em, I will like, the emotion will be different, I mean, if I wake up in the morning I feel like motivated the whole day compared when (I wake up late)".

Emotional maturity means to choose not to keep their emotions hidden instead to express them using efficient methods (Rai \& Khanal, 2017). For example, SMK Jugra professional says that "Because they are still in their early adolescence. They will still possess a certain sense of childishness." For emotion control sub-theme, Kanfer, Ackerman, and Heggestad (1996, p. 186) define emotion-control as "the use of self-regulatory processes to keep performance anxiety and other negative emotional reactions (e.g., worry) at bay during task engagement" (Bell \& Kozlowski, 2008). Goleman (2001) described self-control as a construct of self-management competence. For example, SMK Kalumpang professional says that youth rationalising skills depends on their ability to control their emotions, "if they can control their own emotion, they can think rationally. Meaning that they can produce positive behaviour lah". In addition, S07 uses curse words to show her anger, "But actually not. Sometimes when I feel angry to a person, I really angry that I cursed them. Then, I will just go like that."

Stress management techniques are methods used by youths in dealing with their stress (Nor Diyana, M. S., Murni Zarina, M. R. \& Nur Asiyah, 2012). The stress management issues involved anger management, time management, conflict management and academic performance issues. For example, SMK Kalumpang professionals shared her view that, "Because usually these adolescences will have conflicts. The conflicts may happen either with friends, among friends of the same gender and mostly among friends of different gender". Similarly, S08 shared that,

"I easily get stress, errr..I become, if I have a problem with friends, or we are fighting, or got tease, just a simple-simple matter, I think a lot, overthinking. Like the problems get more branched. I'm going to take SPM right, I can't face it. Feel like hard to face it. I'm not good in studying, I don't know how to be smart, clever, how to understand, it's hard for me. If I ask help from others, it's just the 
same either they want to help and not. Same level. It's really sad but I don't know what to do. Like for example we want to understand the History right ... How we're going to understand it... we can't understand it."

Self-awareness. There are 123 coded segments for this theme. The sub-themes are psychobiology of emotions, emotion regulation, lack of self-acceptance and understanding emotions. Psycho-biology of emotions refers to the emotional trigger of the oxytocinergic system in a person's body which activates the fight or flight responses when the body is in a stressful situation (UvnäsMoberg, Arn, \& Magnusson, 2005). Goleman (2001) also mentioned that 'An understanding of these neurological substrates has critical implications for how people can best learn to develop strengths in the El range of competencies'. For example, STB Marang professional says that "Haluccination, do self-harming. There's a lot of student here who are stress. Cutting ownself. They will take the glass and cut themselves" as problems related to not being aware of their emotions. Student S05 says that he was aware of his emotion when he/she was shivering due to anger after finding out that his/her friend had stolen their personal items.

Emotion regulation. The emotion regulation sub-theme as mentioned by Gross (1998) in a study by Braet et al. (2014) is the process of modifying emotions or situation that elicits the emotion. This is a skill vital in managing self-emotions (Goleman, 2001). An example of response regarding the self-awareness of youths by a UIA professional was that "in the Malaysian context, it should be emotion regulation".

Lack of self-acceptance sub-theme was another issue identified in the self-awareness theme. Categories of lack of self-acceptance in the thematic analysis involved self-esteem and self-efficacy. Self-acceptance is described as having good self-esteem (Vasile, 2013) hence lack of self-acceptance shows low self-esteem. An example is by SMK Danau Kota professional who suggested that adolescents lacked self-acceptance and said, "They would fight with their emotions, everything especially if their parents neglect them".

Understanding emotions refers to knowing the reason behind different emotions or feelings. This sub-theme under the self-awareness theme were issues discussed by both students and professionals. Both STB Marang professional and student S07 mentioned that adolescents did not understand emotions.

Institution negative. These responses are most importantly given by professionals and students residing at one of the Tunas Bakti schools where the research was conducted. Some of the issues that were brought up by them are fear of future and fear of the outside world, lack of volition, punishment types, caretaker assertiveness, staying away from family, having a strict and tight schedule, feeling like being stuck, sad feelings, unable to attend if loss of family member, smoking and stress. 
INTERNATIONAL JOURNAL OF ACADEMIC RESEARCH IN BUSINESS AND SOCIAL SCIENCES Vol. 8, No. 11, Nov, 2018, E-ISSN: 2222-6990 @ 2018 HRMARS

Fear of future and outside world sub-theme was pointed out by juvenile centre residents who shared that, "Like me, the plan, I want to work outside. I take here as an opportunity to work during the rehabilitation. They give here, like and offer. But mostly involve the construction. Contract" and S01 who said, "What I was thinking is like I scared that I cannot. Because it is already my second degree. If I want to do law. To be actually going through that, can I manage that, if, for example, I get married in between that, that's the thing that I don't want to do something that will stop in the middle. When I want to do something, I want to complete."

Punishment types. For example, S07 said, "Maybe sometimes because of other fault, everyone needs to take the responsibility. And they are not feeling satisfied about that. One person make mistake, everyone is being punished. That what make dissatisfaction" and was shared by STB Taiping professional who shared an event that may be a more drastic punishment style which may affect the emotion level of youths at the juvenile centre which is,

"Ok if this is what shows the emotions is, which people say it is too much, we have to punish them. The way of the punishment might be "you sit there, sit down there," for him to feel himself low, his sense of self ... like people say make them feel down, later then he can accept it, his environment, here, he needs to feel down first and then he could accept the environment. How people say, kids here, they want to be shameful first. Then he feels embarrassing, and then he will not repeat it"

For example, STB Sg. Besi professional mentioned about juvenile residents not liking having a lack of volition and said, "they do not like to be coaxed by family and they will easily to get mad. And they do not like if someone scolded at them. They don't like those things. Though, youth's age, they really don't like being scolded. At here, they are not being forced, they have to follow". For the stress sub-theme, S07 said that, "There are some people like that. But here, they are some people that release (stress) through smoking. Non-stop smoking."

Feeling like being stuck. This sub-theme was a sort of complain by S07 who is a student residing at the juvenile delinquent centre who said that, "I like to cook. But now don't have. Because outside I already made an application to get into college but stuck here." Meanwhile, S05 shared that, "Because, when we are happy, we will forget everything. When we do activities and all stuff, we fell happy. Not thinking about family. It is when we do activity. When we feel sad, we will sit still, alone and sometimes we think about our family" who shared that being away from family was also a difficulty of staying at Tunas Bakti schools.

Institution positive. Professionals and students from the Tunas Bakti schools share that some of the positive outcomes of being at the juvenile rehabilitation centre are seeing positive change, talking straightforward, having scheduled work, unity-brotherhood relationship and receiving aid in learning skills. For example, STB Sg. Besi professional talks about the unity-brotherhood sub-theme that, "here in school, they love to have younger brother and older brother. They want sibling. They 
create the sibling and they love each other. When they have siblings, they feel like save, secure, they have gang. They create by themselves. Which mean, even they don't like it, they will find one."

Talking straightforward. Meanwhile, S05 mentions the positive effect of staying at the juvenile rehabilitation centre by saying that, "When I'm in here, I know, I recognize. I can be brave to talk with outside people. Talk to my audience in front of me. I'm doing MC". Whereas, an example of the having scheduled work sub-theme is mentioned by S07 that, "Because, we, here, our timetable is packed. There is no time to think about the outside matters. Maybe the one that only enter here for one month or two, they might think about the outside. After that, workshop division, all of that will disappear."

Ways of coping. Around 129 coded segments were identified for this theme. The sub-themes for ways of coping were interpersonal skills, healthy activities, teaching social intelligence, parenting skills, emotional management skills, self-awareness skills, social religious values and respect and counselling. For example, UPSI professional and S08 explained social religious values and respect when they said that,

"So spiritual yes, spiritual is depend on your background if you are a Muslim, your good guidance in whether you are a Muslim or you are Hindu, Buddha or whatever religion you come from ... emm spiritual emm your religious background must be strong". (UPSI Professional)

"Errr I'm more to confiding to God, I tell Him everything, I complain errr the things they wouldn't be able to understand I'm going through... they don't know much. If they do help me then after two days, they let me alone, pretending like nothing has happened. Like a stranded man on an island" (S08)

Healthy activities. When asked about what they would do to manage with social emotions, most replied saying they would play sport activities like football. For example, S07 said, "As for me, I like to invite people to play games. Doesn't matter what kind of game, just ask them to play. Like playing carom.

Teaching social intelligence. When asked about the ways to manage social emotions, an UPSI professional mentioned that, "the skill on teaching social intelligence because we have but I'm not touched it". Moreover, emotional management skills was emphasised by STB Telok Air Tawar professional by saying that, "Because we really organise activities for the residents here so that they will be occupied".

Self-awareness skills sub-theme was shared by a UPSI professional who said, "guidance on how to know yourself". Parenting skills. Example of response related to developing parents skills in dealing with emotional problems among youths was shared by a UIA professional who said, "combine of parents and the children. So, we teach children how to regulate their emotion, the parents have to be aware of that. So when we teach the children communication, how to express 
INTERNATIONAL JOURNAL OF ACADEMIC RESEARCH IN BUSINESS AND SOCIAL SCIENCES Vol. 8, No. 11, Nov, 2018, E-ISSN: 2222-6990 @ 2018 HRMARS

their emotion appropriately way, so they still have to do role play with the parents because it starts with the parents at home"

Emotion management skills. Several responses for emotion management skills involve assertive skills. For example, UKM professional mentioned, "And the skill how to say 'No'. Simple skill. When we say about decision making is quite big for them actually. How to say 'No' and how to say 'Yes' at the right thing or wrong thing".

\section{Discussion}

Research question 1: Which emotional issues are more evident among youngsters?

There are nine themes generated from the thematic analysis using the MAXQDA software. They are professional competence, living environment, relationship management, social awareness, selfmanagement, self-awareness, institution negative and institution positive and ways of coping. Some of the themes have sub-themes.

The first theme identified is professional competence with some responses showing a lack of professional training or understaffing issues that may disrupt professional competency to work in their area. This is similar to a research by Noor Hafizah (2016) that there were too many residents but only one religious teacher. The professional interviewees ranged from counsellors, school teachers and managing officers at the juvenile centres. These findings are similar to a study by Aga Mohd Jaladin (2013) who found that lack of experience and exposure to diverse cultures and resistance and lack of support system may become challenges experienced by a counsellor in Malaysia. This may affect the rehabilitation process of juvenile residents in the center as mentioned by Hezzrin, Nor Jana, Norulhuda and Mohammad Rahim (2016) and Azizi, Kiaw Geok and Amir Hamzah (1989) that several programs organised in rehabilitation centers were not very effective.

The second theme is living environment. The sub-themes of living environment involve negative lifestyle, family background, education system and social media. Family background affecting the emotional intelligence level is contrary to findings by Afzal and Afzal (2016) which showed that family structure as well as number of siblings did not show significant effect on the emotional intelligence level of secondary school students. However, a study conducted by Fatimah Hanim, Mahlindayu, Muniruddin, Nik Nabila Ramiz and Nur Ili Diyana (2013) which showed that family background in specific family income explained the emotional intelligence level of university students. Research regarding whether education system affects the emotional level of adolescents is lacking. Meanwhile, the study by van der Merwe (2014) identified that certain parts of media use has been thought to have negative impact on an adolescents' overall psychological well-being. Similarly, a study by Abdelkader and Elnakeeb (2017) showed that media use time and emotional intelligence are positively related.

The third theme is relationship management. Some of the sub-themes that led to the emergence of this theme were express emotions, problem solving and communication. Express emotion is the ability to talk or show their true feelings in a social setting. Emotion expression as in 
the USMEQ-i is already established as a significant part of emotional intelligence (Yusoff, 2012) and self-management techniques (Shepardson, Tapio, \& Funderburk, 2017). Problem solving skills is a vital part of relationship management as a research by Atasayar (2012) showed that having skills in problem-solving resulted in lower levels of loneliness. Meanwhile, previous study by Najib, Che Su and Zarina (2015) showed that students with high emotional intelligence level were better in their communication skills in addition to a study whereby communication had positive significant association with customer relationship management.

The fourth theme is social awareness. The main code that represented social awareness was interpersonal relationship. Some of the sub-categories that helped explain interpersonal issues were social learning, empathy, need for attention, peer support, teacher support and others. Social learning theory (Strickland \& Pittman, 1984) and empathy (Tehrani-Javan, Pashang \& Mashayekh, 2016) has been well established to affect interpersonal influences. Meanwhile, social support as explained by Virtanen and Isolatus (2014) is the act being aware of void or emptiness in self and to fill that emptiness with a person's life experience as well as others thus showing that support from others is a crucial interpersonal aspect. Meanwhile, studies also indicate that interpersonal attention plays an important role in improving friendship (Ohtsubo et al., 2014).

The fifth theme is self-management. The sub-themes that were grouped into selfmanagement are motivation, maturity, controlling emotions and stress management. Motivation indeed helps improve self-management as supported in a study by Newton, Asimakopoulou and Scambler (2015) whom showed that motivation predicted successful self-management styles in type 2 diabetes patients. Whereas, maturity (Ingersoll, Orr, Herrold, \& Golden, 1986) and controlling emotions (Kanfer \& Gaelick-Buys, 1991) is also an important aspect for self-management. Meanwhile, stress management (Kang, Kwon, \& Yang, 2016; Safari, 2015) issues involved anger management (Safari, 2015), conflict management (Hooda \& Gurmeet, 2015), time management and academic performance (Khatib, 2014) are issues related to self-management.

The sixth theme is self-awareness. The sub-themes are psycho-biology of emotions, emotion regulation, lack of self-acceptance and understanding emotions. Psycho-biology of emotions categorized under self-awareness is similar to findings by Vaitl et al. (2005) which portrayed that physical, psychological and physiological stimulation resulted in different consciousness levels. Whereas, in a study by Subic-Wrana et al. (2014), emotion awareness is an important aspect for emotion regulation. Self-awareness positively predicts acceptance in a study by Sutton (2016) hence categorised under self-awareness theme in the thematic analysis. Meanwhile, understanding emotions is a definition for self-awareness which is to understand own and other's emotions (Saiful Bahri, Ahmad Fuad \& Abd Rahman, 2011)

The seventh theme is institution negative. Some of the issues that were brought up by them are fear of future and fear of the outside world, lack of volition, punishment types, caretaker assertiveness, staying away from family, having a strict and tight schedule, feeling like being stuck, sad feelings, unable to attend if loss of family member, smoking and also stress. Fear of future and 
outside world responses probably due to problems that they face in getting jobs when they leave as reported by Azizi, Kiaw Geok and Amir Hamzah (1989). However, the other responses were not reported as negatively impacting the residents. More research needs to be done to confirm this.

The eighth theme is institution positive. Professionals and students from the Tunas Bakti schools share that some of the positive outcomes of being at the juvenile rehabilitation centre are seeing positive change, talking straightforward, having scheduled work, unity-brotherhood relationship and receiving aid in learning skills. This is similar to findings by Azizi, Kiaw Geok and Amir Hamzah (1989).

The ninth theme is ways of coping. This theme was identified based upon the suggestions given by professionals and students for ways to overcome or cope with emotion problems. The subthemes identified in this study are interpersonal skills, module suggestions, conducting healthy activities, teaching social intelligence, parenting skills, emotion management skills, self-awareness skills, social religious values and respect as well as counselling. These methods are similar to those mentioned by Skinner and Zimmer-Gembeck (1979) which are problem-solving, information-seeking, helplessness, escape, support-seeking, delegation, social isolation, accommodation, negotiation, submission and opposition and also to those mentioned in the study by Shepardson, Tapio and Funderburk (2017) which are self-care (relaxation and exercise), cognitive (redirecting thoughts), avoidance (isolation), connectedness with family, pets and social and doing pleasurable activities such as outdoor activities, music and media.

\section{Limitations, Implications and Future Recommendations Limitations}

Initially this study sample population included the Henry Gurney schools for juvenile delinquents. However, our application was declined by the Malaysian Prison Department hence disabling us from conducting our research there. Besides, another Tunas Bakti school in Jerantut, Pahang was under construction hence allowing us to collect data from only four Tunas Bakti school instead of five. This may have caused issues in the final results.

\section{Implications}

The findings of the research can help provide better knowledge regarding more current issues of emotional problems faced by adolescents in Malaysia. Besides the results cater youth organizations and governmental organizations to modify their approaches toward the improvement of developing youth skills in this era. The results also show specific emotional competency issues faced by adolescents for which the Emotional Competency Module is developed. This module will benefit all professionals and adolescents in handling their emotions in future.

The findings revealed that professional competency in handling emotional problems among adolescents have certain issues. The professionals in this study include school counsellors and juvenile rehabilitation centre staffs. Hence, further actions can be taken by schools and the government to improve their competency level in dealing with adolescents. Besides, another theme 
in the qualitative analysis revealed that there are certain negative aspects of the institution that may also affect adolescents emotionally. These may have been neglected by the authorities of the juvenile rehabilitation centres and allows them to improve their staff competency in dealing with these issues. Some of the sub-themes that require attention are fear of future and fear of the outside world, lack of volition, punishment types, caretaker assertiveness, staying away from family, having a strict and tight schedule, feeling like being stuck, sad feelings, unable to attend if loss of family member, smoking and also stress. These details provide information to the Tunas Bakti school authorities to improve their techniques to cater to their resident's needs.

\section{Future Recommendations}

This study has shown significant results in the emotional intelligence of adolescents in Malaysia. Due to a monotonous overview of only emotional intelligence, future researches may want to explore relationships between the emotional intelligence with social and cognitive aspects of adolescents. Besides, researches exploring the level of emotion intelligence among toddlers and children are still lacking in Malaysia. Hence, this research may be a stepping stone into a deeper developmental psychology research.

Many themes which emerged from the qualitative study need further research to be confirmed. Some of them were the juvenile rehabilitation institution negative and positive effects on adolescents residing there. More research on tackling these identified problems are needed to deal with their emotional problems. Besides, more studies regarding the competency of professionals in handling with adolescent problems is vital. One of the thematic analysis findings revealed that professionals tasked with dealing with the adolescents may lack the training. Hence, requiring more research to prove this.

\section{Conclusion}

Qualitative findings revealed that professional competency in handling emotional problems among adolescents have certain issues. The professionals in this study include school counsellors and juvenile rehabilitation center's staffs. Hence, further actions can be taken by schools and the government to improve their competency level in dealing with adolescents. Besides, another theme in the qualitative analysis revealed that there are certain negative aspects of the institution that may also affect adolescents emotionally. These may have been neglected by the authorities of the juvenile rehabilitation centers and allows them to improve their staff competency in dealing with these issues. Some of the sub-themes that require attention are fear of future and fear of the outside world, lack of volition, punishment types, caretaker assertiveness, staying away from family, having a strict and tight schedule, feeling like being stuck, sad feelings, unable to attend if loss of family member, smoking and also stress. These details provide information to the Tunas Bakti school authorities to improve their techniques to cater to their resident's needs. This study have provided the theoretical background to develop emotional competency module which can help the youngsters to manage and improve their emotional competency. The study has contributed to find the grounded information's related to youngster's emotional issues. The further recommendations are to develop the effective emotional competency module. 
INTERNATIONAL JOURNAL OF ACADEMIC RESEARCH IN BUSINESS AND SOCIAL SCIENCES

Vol. 8, No. 11, Nov, 2018, E-ISSN: 2222-6990 @ 2018 HRMARS

\section{Acknowledgment}

We acknowledge Ministry of Higher Education for this Fundamental Research Grant Scheme, Department of Higher Education, Malaysia, Research \& Development Grants, which is aimed to develop emotional competency module.

\section{References}

Abdelkader, W., \& Elnakeeb, M. (2017). The relationship between the use of media and emotional intelligence among youth nursing students, 6(5), 63-77. https://doi.org/10.9790/19590605016377

Abdollahi, A., Carlbring, P., Khanbani, M., \& Ghahfarokhi, S. A. (2016). Emotional intelligence moderates perceived stress and suicidal ideation among depressed adolescent inpatients. Personality and Individual Differences, 102, 223-228. https://doi.org/10.1016/j.paid.2016.07.015

Abdollahi, A., Yaacob, S. N., Talib, M. A., \& Ismail, Z. (2015). Social Anxiety and Cigarette Smoking in Adolescents: The Mediating Role of Emotional Intelligence. School Mental Health, 7(3), 184192. https://doi.org/10.1007/s12310-015-9141-4

Adigwe, J. C. (2015). Emotional Intelligence and problem solving achievement of chemistry students. ATBU, Journal of Scince, Technology and Education (JOSTE), 3(1), 80-95.

Afzal, M. T., \& Afzal, M. (2016). Relationship of family structure and emotional intelligence of secondary school students in Islamabad. American Journal of Educational Research, Vol. 4, 2016, Pages 685-688, 4(9), 685-688. https://doi.org/10.12691/EDUCATION-4-9-7

Alsharari, Y. S., Fadzil Shah, A., Che Azlan, T., \& Rushami Zien, Y. (2017). The association between communication, customer relationship management and organisational performance: evidence from the Saudi Arabia hospitals. Journal of Management Research, 9(4), 57. https://doi.org/10.5296/jmr.v9i4.11776

Bacon, A. M., Burak, H., \& Rann, J. (2014). Sex differences in the relationship between sensation seeking, trait emotional intelligence and delinquent behaviour. Journal of Forensic Psychiatry and Psychology, 25(6), 673-683. https://doi.org/10.1080/14789949.2014.943796

Balluerka, N., Aritzeta, A., Gorostiaga, A., Gartzia, L., \& Soroa, G. (2013). Emotional intelligence and depressed mood in adolescence : A multilevel approach. International Journal of Clinical and Helath Psychology, 1(13), 110-117.

Bell, B. S., \& Kozlowski, S. (2008). Active learning : Effects of core training design elements on selfregulatory processes, learning, and adaptability. Journal of Applied Psychology, 93(2), 296316. https://doi.org/10.1037/0021-9010.93.2.296

Bibi, S., \& Saqlain, S. (2016). Relationship between emotional intelligence and self-esteem among Pakistani university students. Cell \& Developmental Biology, 6(4). https://doi.org/10.4172/2161-0487.1000279

Braet, C., Theuwis, L., Van Durme, K., Vandewalle, J., Vandevivere, E., Wante, L. \& Goossens, L. (2014). Emotion regulation in children with emotional problems. Cognitive Therapy and Research, 38(5), 493-504. https://doi.org/10.1007/s10608-014-9616-x

Campbell, D.G. (1999). "An empirical comparison of three theories of decent ring", Dissertation Abstracts International 50(12):3792-4320, (UMI No. 9012890). 
INTERNATIONAL JOURNAL OF ACADEMIC RESEARCH IN BUSINESS AND SOCIAL SCIENCES

Vol. 8, No. 11, Nov, 2018, E-ISSN: 2222-6990 @ 2018 HRMARS

Castilho, P., Carvalho, S. A., Marques, S., \& Pinto-Gouveia, J. (2017). Self-compassion and emotional intelligence in adolescence: A multigroup mediational study of the impact of shame memories on depressive symptoms. Journal of Child and Family Studies, 26(3), 759-768.

https://doi.org/10.1007/s10826-016-0613-4

Chong, A. M., Lee, P. G., Roslan, S., \& Baba, M. (2015). Emotional intelligence and at-risk students. SAGE Open, 5(1). https://doi.org/10.1177/2158244014564768

Cobos-Sanchez, L., Flujas-Contreras, J. M., \& Gomez-Becerra, I. (2017). The role of emotional intelligence in psychological adjustment among adolescents | Inteligencia emocional y su papel en el ajuste psicol?gico en la adolescencia. Anales de Psicologia, 33(1), 66-73.

https://doi.org/10.6018/analesps.33.1.240181

Diyana, M. S., Murni Zarina, M. R. \& Nur Asiyah, R. (2012). Halal traceability framework for halal food production. World Applied Sciences Journal, 17(SPL.ISS1), 1-5. https://doi.org/10.7763/IPEDR.

Ensari, P. (2017). How to improve emotional intelligence and social skills among adolescents: The development and test of a new microexpressions training. Journal of Behavioral and Brain Science, 07(05), 211-225. https://doi.org/10.4236/jbbs.2017.75016

ERÖZKAN, A. (2014). Analysis of social problem solving and social self-efficacy in prospective teachers. Educational Sciences: Theory \& Practice, 14(2), 447-455. https://doi.org/10.12738/estp.2014.2.2014

Fatimah, Hanim. A., Mahlindayu, T., Muniruddin, O., Nik, Nabila. Ramiz. Y. \& Nur, Ili. Diyana, M. Z. (2013). Personal , family and academic factors towards emotional intelligence : a case study. International Journal of Applied Psychology, 3(1), 1-6. https://doi.org/10.5923/j.ijap.20130301.01

Goleman, D. (2001). An El-based theory of performance. In C. Cherniss \& D. Goleman (Eds.), The emotionally intelligent workplace (pp. 27-44). https://doi.org/10.1017/CB09781107415324.004

Hassan, J., Saeid, J., Hashim Fauzy, Y., \& Khalil, M. N. (2014). The impact of emotional intelligence on communication effectiveness: Focus on strategic alignment. African Journal of Marketing Management, 6(6), 82-87. https://doi.org/10.5897/AJMM2010.036

Hsieh, M.-C., Wang, T.-S., Fan, C.-P., \& Huang, C.-I. (2014). A study of the emotional intelligence and interpersonal relationships of college students in Southern Taiwan. Universal Journal of Management, 2(8), 133-138. https://doi.org/10.13189/ujm.2014.020803

Lim, T. S. (2011). Gender differences in emotional intelligence: Are you as smart as you think emotionally?, (April), 1-68. https://doi.org/10.1017/CBO9781107415324.004

Liu, Y., Wang, Z., \& Lü, W. (2013). Resilience and affect balance as mediators between trait emotional intelligence and life satisfaction. Personality and Individual Differences. https://doi.org/10.1016/j.paid.2012.12.010

Maizatul Akmal Mohd, M., Norhaslinda, H., \& Norhafizah, A. H. (2013). The influence of emotional intelligence on academic achievement. Procedia - Social and Behavioral Sciences, 90(InCULT 2012), 303-312. https://doi.org/10.1016/j.sbspro.2013.07.095

Najib, A. M., Che Su, M. \& Zarina, M. S. (2015). Emotional intelligence: Its relationship with communication and information technology skills. Asian Social Science, 11(15), 267-274. 
INTERNATIONAL JOURNAL OF ACADEMIC RESEARCH IN BUSINESS AND SOCIAL SCIENCES

Vol. 8, No. 11, Nov, 2018, E-ISSN: 2222-6990 @ 2018 HRMARS

https://doi.org/10.5539/ass.v11n15p267

Nasir, Che . M. \& Mohd, Ali. Hanafiah. N. (2015). Faktor internal individu dan delinkuensi : Kajian ke atas remaja perempuan di asrama akhlak. Jurnal Pembangunan Sosial, 18(June), 185-202.

Pelz, D. C. (1962). Self-determination and self-motivation in relation to performance: $A$ study of interaction effects. University of Michigan.

Rai, D., \& Khanal, Y. K. (2017). Emotional intelligence and emotional maturity and their relationship with academic achievement of college students in Sikkim. International Journal of Education and Psychological Research (IJEPR), 6(2), 1-5. Retrieved from http://ijepr.org/doc/V6_Is2_June17/ij1.pdf

Romero, C., Master, A., Paunesku, D., Dweck, C. S., \& Gross, J. J. (2014). Academic and emotional functioning in middle school: The role of implicit theories. Emotion, 14(2), 227-234. https://doi.org/10.1037/a0035490

Sharma, N., Prakash, O., Sengar, K. S., Chaudhury, S., \& Singh, A. R. (2015). The relation between emotional intelligence and criminal behavior: A study among convicted criminals. Industrial Psychiatry Journal, 24(1), 54-58. https://doi.org/10.4103/0972-6748.160934

Tunggak, B., Ngadi, S., \& Abu Naim, H. (2015). Students delinquency and proposed solutions through teen model of conduct/integrated muslim students. Jurnal Hadhari, 7(72), 11-30.

Uvnäs-Moberg, K., Arn, I., \& Magnusson, D. (2005). The psychobiology of emotion: The role of the oxytocinergic system. International Journal of Behavioral Medicine, 12(2), 59-65. https://doi.org/10.1207/s15327558ijbm1202_3

Van-der, Merwe. P. (2014). Adolescence, internet use, social adjustment and emotional intelligence. Mediterranean Journal of Social Sciences, (September). https://doi.org/10.5901/mjss.2014.v5n23p2327

Vasile, C. (2013). An evaluation of self-acceptance in adults. Procedia - Social and Behavioral Sciences, 78, 605-609. https://doi.org/10.1016/j.sbspro.2013.04.360

Vossen, H. G. M., \& Valkenburg, P. M. (2016). Do social media foster or curtail adolescents' empathy? A longitudinal study. Computers in Human Behavior, 63, 118-124. https://doi.org/10.1016/j.chb.2016.05.040

Wilks, D. C., Neto, F., \& Mavroveli, S. (2015). Trait emotional intelligence, forgiveness, and gratitude in Cape Verdean and Portuguese students. South African Journal of Psychology, 45(1), 93-101. https://doi.org/10.1177/0081246314546347

Yusoff, M.S.B., Rahim, A.F.A, Esa, A.R. (2010) The USM emotional quotient inventory (USMEQ-i) manual. Kota Bharu. KKMED Publications.

Zhao, J., Kong, F., \& Wang, Y. (2013). Shyness and subjective well-being: The role of emotional intelligence and social support. Social Indicators Research, 114(3), 891-900. https://doi.org/10.1007/s11205-012-0178-6

Zhao, J., Tan, M., Gao, L., \& Wang, Y. (2017). Shyness and loneliness: Contributions of emotional intelligence and social support. Current Psychology, (1986), 1-7. https://doi.org/10.1007/s12144017-9640-6 